\title{
The WOCE Model in the Western Equatorial Atlantic: Upper Layer Circulation
}

\author{
Friedrich A. Schott and Claus W. Böning \\ Institut für Meereskunde an der Universität Kiel, Germany
}

\begin{abstract}
A high-resolution general circulation model of the North Atlantic, first developed at the National Center for Atmospheric Research and then run at the Institut für Meereskunde in Kiel for two different wind climatologies and reduced vertical friction, is evaluated in the upper $500 \mathrm{~m}$ for the western tropical Atlantic, $5^{\circ} \mathrm{S}$ to $15^{\circ} \mathrm{N}$. Although the general features of the vigorous seasonal circulation changes documented in previous studies and in the earlier high-resolution model of Philander and Pacanowski (1986a) are reproduced, there are some interesting differences. Lack of eastward penetration of the Equatorial Undercurrent (EUC) and a thermocline that is too diffuse are model deficiencies due to the constant vertical eddy diffusion coefficient. In the lower friction case the undercurrent partially surfaces in the west, causing an eastward surface current on the equator, which is not apparent in the earlier model studies. Further, the zonal currents, in the low-friction version, have high-velocity bands, resulting, e.g., in two separate current cores in the North Equatorial Countercurrent (NECC) region; and an eastward surface core just south of the equator, connected to the EUC. Particularly interesting are equatorward undercurrents along the western boundary, one of which has already been confirmed in recent measurements off French Guyana. In winter it connects with the EUC in the model, in summer with the NECC. A northward undercurrent in the model exists off Brazil, between $5^{\circ}$ and $10^{\circ} \mathrm{S}$, but that is already close to the southern boundary of the model domain. The annual mean throughflow from the southern hemisphere into the Caribbean along the western boundary is small in the model, and in particular, there is no enhanced throughflow in winter, when the cross-equatorial North Brazil Current transport is not taken up by the NECC.
\end{abstract}

\section{INTRODUCTION}

The western tropical Atlantic is a boundary regime with a vigorously changing seasonal circulation. The basic elements of the connection between the mean zonal flows and the boundary regime have been known for more than a decade [e.g., Metcalf and Stalcup, 1967; Cochrane et al., 1979]. The South Equatorial Current (SEC) from south of the equator turns northwestward along the coast of North Brazil as a western boundary current, called the North Brazil Current (NBC) beginning at $2^{\circ}-3^{\circ} \mathrm{S}$. After crossing the equator, its lower part turns back and eastward just north of the equator and feeds into the Equatorial Undercurrent (EUC), while the near-surface part continues to near $5^{\circ} \mathrm{N}$ and then turns into the North Equatorial Countercurrent (NECC).

The seasonal cycle of this regime has been inferred from analyses of historical ship drifts and surface drifters [Richardson and Walsh, 1986; Richardson and Reverdin, 1987] and evaluation of the high-resolution numerical model of Philander and Pacanowski $[1986 a, b]$. These results show the NECC to have its maximum in late summer and its minimum in late winter, with surface currents in the western part then even reversing to westward. In summer the NBC/NECC regime between $3^{\circ}$ and $7^{\circ} \mathrm{N}$ shows a pronounced retroflection with strong oscillations in the 40- to 60-day period band, and with water mass transfer northward through eddy shedding [Johns et al., 1990]. In winter, the cross-equatorial NBC has to merge with the then westward flowing NECC, and as a plausible consequence, an enhanced NBC north of $5^{\circ} \mathrm{N}$ during this season was postulated in these earlier studies. The evidence for enhanced northwestward flow toward the Caribbean in winter is, however, not conclusive. Also, the

Copyright 1991 by the American Geophysical Union.

Paper number 90JC02683. 0148-0227/91/90JC-02683\$05.00 annual cycle of western Caribbean inflow is still unclear. It is possible that part of the combined NBC and NECC flow in winter turns offshore before reaching the Caribbean

The thermohaline cell of the Atlantic carries 10-15 Sv of warm water northward and cold North Atlantic Deep Water (NADW) southward as required by global water mass analysis [Gordon, 1986], inversion of hydrographic section data and heat flux considerations [Wunsch, 1984; Hall and Bryden, 1981], and earlier results of lower resolution numerical modeling [Sarmiento, 1986]. Water masses of South Atlantic origin are not found in the warm water sphere east of the Bahamas [Olson et al., 1984] but must find pathways through the Caribbean passages to the Florida Straits [Schmitz and Richardson, 1991; Wunsch and Roemmich, 1985]. Hence, for the mean circulation, one should expect that a significant amount of water from the SEC reaches the Caribbean and Florida Current.

In this paper we shall evaluate the upper layer circulation of the western tropical Atlantic in a high-resolution model, developed in recent years at the National Center for Atmospheric Research (NCAR) [Bryan and Holland, 1989] and also run in a modified version at the Institut für Meereskunde (IfM) in Kiel. We will present the seasonal cycle of currents and transports through crucial sections between $5^{\circ} \mathrm{S}$ and the inflow into the Caribbean (Figure 1) and compare these results with evidence from the historical data file and more recent observations. Results from the model had already suggested an equatorward undercurrent in the North BrazilGuyana boundary current regime that had hitherto not been recognized in observations but indications for which were recently detected in moored current meter observations [Johns et al., 1990] and Pegasus profiling (C. Colin, persona] communication, 1989) off French Guyana.

Sections of particular interest to us are $53^{\circ} \mathrm{W}$ off Guyana, where much of the recent field work in the Subtropical 


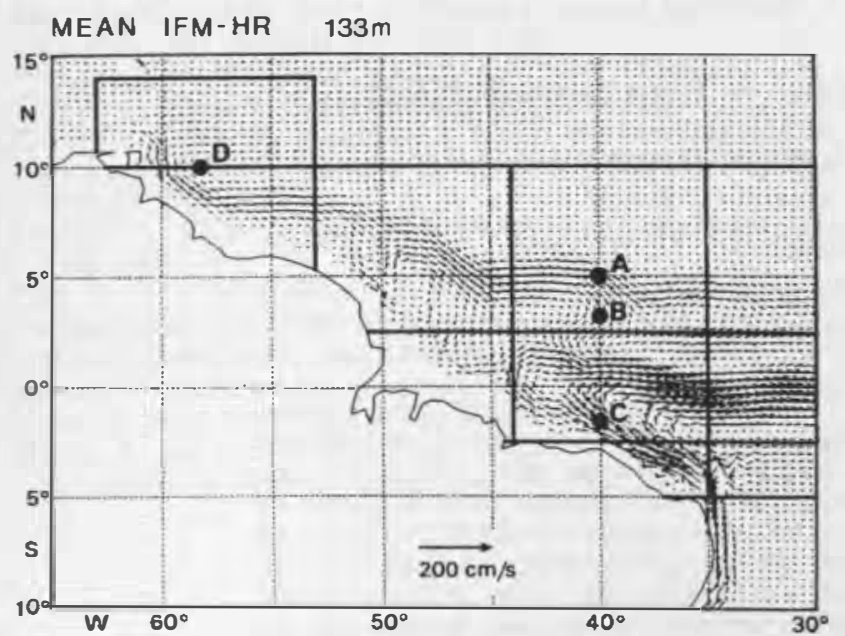

Fig. 1. Annual mean currents at level $4(133 \mathrm{~m})$ in IFM-HR model, locations of sections used for box calculations and of points used for variance calculations.

Atlantic Climate Studies (STACS) program and by the Cayenne-based group of Institut Français de Recherche Scientifique pour le Développement en Coopération (ORSTOM) has been carried out; $44^{\circ} \mathrm{W}$, where conductivity, temperature, and depth (CTD)/Pegasus sections of NOAA Atlantic Oceanographic and Meteorological Laboratories (AOML) and IfM Kiel are being taken and moored stations deployed during 1989-1991; and 5 ${ }^{\circ}$, where CTD/Pegasus measurements are planned (Figure 1).

We will also compare transports of this model, both mean and seasonal, with results from the earlier, regional highresolution model of Philander and Pacanowski [1986a,b] and also with the global high-resolution model of Seminer and Chervin [1988] that has recently been expanded to include seasonal forcing.

\section{WOCE Model and OUtPut FieldS}

The high-resolution model of the wind-driven and thermohaline circulation had been developed by Bryan and Holland [1989] as a Community Modeling Effort (CME) for the World Ocean Circulation Experiment (WOCE). Mass transports for different wind climatologies have been presented by Böning et al. [1991]. The model domain covers the Atlantic Ocean from $65^{\circ} \mathrm{N}$ to $15^{\circ} \mathrm{S}$. The horizontal resolution is $0.33^{\circ}$ in latitude and $0.4^{\circ}$ in longitude. In the vertical, 30 levels are used with a spacing of $35 \mathrm{~m}$ near the surface, increasing smoothly to $100 \mathrm{~m}$ near $500-\mathrm{m}$ depth and $250 \mathrm{~m}$ near $1100-\mathrm{m}$ depth, from which point on, downward resolution stays constant. The surface boundary condition for temperature is the heat flux condition given by $\operatorname{Han}$ [1984], and for salinity, a relaxation to the seasonal climatology of Levitus [1982] is applied, with a time scale of 50 days. At the northern and southern boundaries the model domain ends in buffer zones, where temperature and salinity are forced to the seasonally varying Levitus [1982] climatology. In the southern buffer zone an artificial transformation of southward flowing NADW into northward flowing, warm upper layer flow takes place.

Two versions of this model have been evaluated, all for year 23 of a 25 -year run. First is the CME of NCAR (F.
Bryan, personal communication, 1988), forced with the Hellerman and Rosenstein [1983] (hereinafter referred to as HR) wind stress climatology with a vertical momentum diffusion coefficient of $30 \mathrm{~cm}^{2} \mathrm{~s}^{-2}$, called NCAR in the following, second is a run of IfM Kiel, also forced with HR winds but using a vertical viscosity of only $10 \mathrm{~cm}^{2} \mathrm{~s}^{-2}$, called IFM-HR in the following.

A third version of the model has been run at IfM Kiel, also with the lower vertical friction but forced with the wind stress climatology of Isemer and Hasse [1987] (hereinafter referred to as IH), called IFM-IH in the following. Since IH wind stresses are only available north of the equator, the wind stresses used for this third version are HR south of the equator, IH north of the $5^{\circ} \mathrm{N}$; and both climatologies are merged in the latitude belt $0-5^{\circ} \mathrm{N}$. Hence IFM-IH, which showed drastic differences compared to IFM-HR for the western boundary transports of the subtropics [Böning et al., 1991], with a much better representation of the observed Florida Current transports, will only be of limited use for the tropics. IFM-HR will therefore be considered as the standard case in the following.

In many respects, the WOCE Atlantic model is similar to the now-classical model of Philander and Pacanowski [1986a] (hereinafter referred to as PP) for the equatorial region; i.e., both are based on the primitive equation model of Bryan [1969] and Cox [1984], and both use the same latitudinal grid spacing. Major influences on the structure of the upper layer circulation can be expected from the following.

1. The different parameterization of vertical mixing: PP used a Richardson number dependent vertical mixing coefficient, along with a higher vertical resolution in the upper $200 \mathrm{~m}$. A constant grid box thickness of $10 \mathrm{~m}$ was used in the upper $100 \mathrm{~m}$. In the upper $10 \mathrm{~m}$, PP prescribed a minimum value for the viscosity of $10 \mathrm{~cm}^{2} \mathrm{~s}^{-2}$.

2. The different spacing in zonal direction ( $\left(1^{\circ}\right.$ in PP), and the different parameterization of subgrid-scale horizontal mixing: PP used a Laplacian eddy viscosity and diffusivity scheme with coefficients of $2 \times 10^{7} \mathrm{~cm}^{2} \mathrm{~s}^{-1}$ equatorward of $10^{\circ}$ latitude. (Poleward of $10^{\circ}$ latitude their meridional resolution gets coarser.) In the WOCE model a biharmonic friction scheme (viscosity $2.5 \times 10^{19} \mathrm{~cm}^{4} \mathrm{~s}^{-1}$, diffusivity $2.5 \times 10^{19} \mathrm{~cm}^{4} \mathrm{~s}^{-1}$ ) is employed which allows, for the same control of computational noise, a drastic reduction of the frictional influence in mesoscale features. The frictional damping times $\boldsymbol{T}$ of a wavelike disturbance associated with these mixing schemes can be estimated from

$$
\begin{aligned}
T_{\text {Laplacian }} & =\lambda^{2} / A(2 \pi)^{2} \\
T_{\text {Biharmonic }} & =-\lambda^{4} / A(2 \pi)^{4}
\end{aligned}
$$

where $\lambda$ is the wavelength and $A$ the eddy coefficient. Whereas grid noise in both models is controlled by similar frictional time scales $(0.8$ days for $\lambda=75 \mathrm{~km})$, the damping of $400 \mathrm{~km}$ waves is much weaker with the biharmonic scheme ( 770 days) than with the Laplacian scheme ( 24 days). The latter time scale is similar to the decay times associated with the vertical mixing in the upper layer: for vertical wavelengths of $200 \mathrm{~m}(300 \mathrm{~m})$, and an eddy viscosity of 10 $\mathrm{cm}^{2} \mathrm{~s}^{-1}$, we can estimate a $T_{\text {vertical }}$ of 11 days ( 25 days).

In PP and related SEQUAL/FOCAL papers [e.g., Richardson and Philander, 1986], the model was forced with HR 

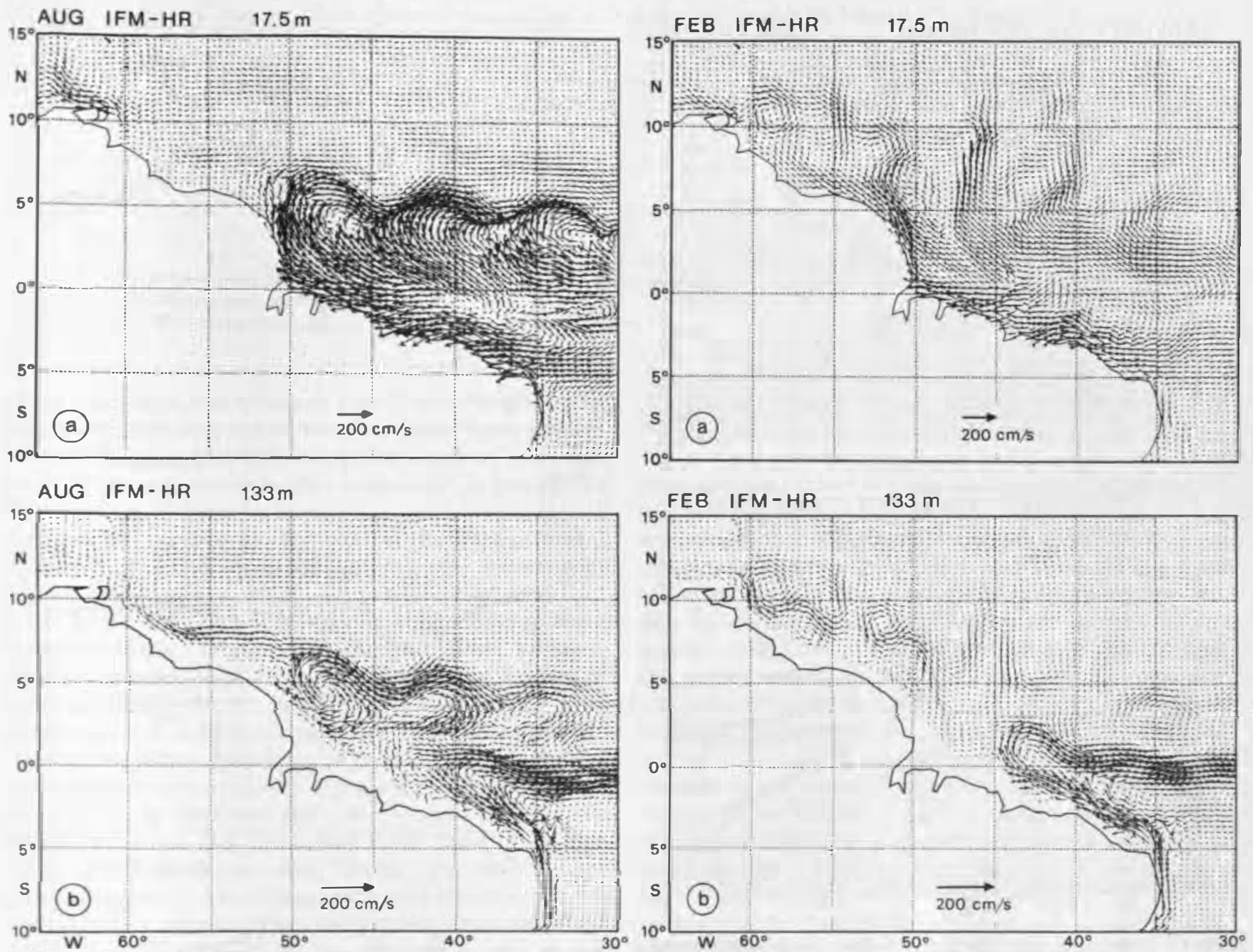

Fig. 2. Currents in IFM-HR model for August: $(a)$ surface and (b) $133 \mathrm{~m}$.

winds. The surface currents along $30^{\circ} \mathrm{W}$ we will be using for comparison with the WOCE model are taken out of those publications for that wind climatology. For evaluation of transports and subsurface currents, we use a version of the PP model forced with the FOCAL winds of 1983. To distinguish both cases in the following, we will refer to the original PP model as PP-HR, and the latter as PP-F.

In the WOCE model versions described above, windforced deepening of the mixed layer, i.e., entrainment from the second layer into the first, etc., does not occur. Very recently, a further modification has been introduced: the inclusion of Kraus and Turner [1967] type mixed layer dynamics. This version, however, is still in an early exper imental stage and will only be compared qualitatively in the following.

\section{Circulation Patterns in Summer and Winter}

Current vectors for the surface layer for August (Figure $2 a$ ) show the south equatorial branch of the SEC (SSEC) inflow at $3^{\circ}-5^{\circ} \mathrm{S}$, the cross-equatorial $\mathrm{NBC}$, and the retroflection into a meandering NECC. The NECC is also supplied from a latitude belt north of the equator, by eastward recirculation out of the northequatorial branch of the SEC. A

Fig. 3. Same as Figure 2, but for February.

weak northwestward coastal current toward the Caribbean is apparent. The summer situation begins to develop in early June and continues similar to Figure $2 a$ until early December when the meander pattern begins to dissolve. The meander crests and troughs keep an almost constant position during this circulation phase. In winter (Figure $3 a$ ) the SSEC inflow at $3^{\circ}-5^{\circ} \mathrm{S}$ continues, apparently weaker than in summer: but north of $2^{\circ} \mathrm{N}$, the circulation is unorganized and generally westward. The northwestward boundary current off Guyana is now stronger with inflow from the westward drift in the NECC regime.

At the undercurrent level, the cross-equatorial flow out of the SSEC turns into the EUC in August (Figure 2b), while the deeper parts of the NECC at its western extension are supplied partially by an equatorward undercurrent off Guyana. In February (Figure $3 b$ ) this undercurrent continues farther southward and feeds into the EUC, adding to the supply from the SSEC.

Salinity at the EUC level at the end of both circulation seasons, December and April, shows the extremes of water mass redistribution through the seasonal current patterns. In December (Figure 4a), a core of northern high-salinity water propagates from about $60^{\circ} \mathrm{W}$ eastward, to form a highsalinity wedge along the NECC. In April the high salinity carried by the undercurrent off Guyana connects with the 

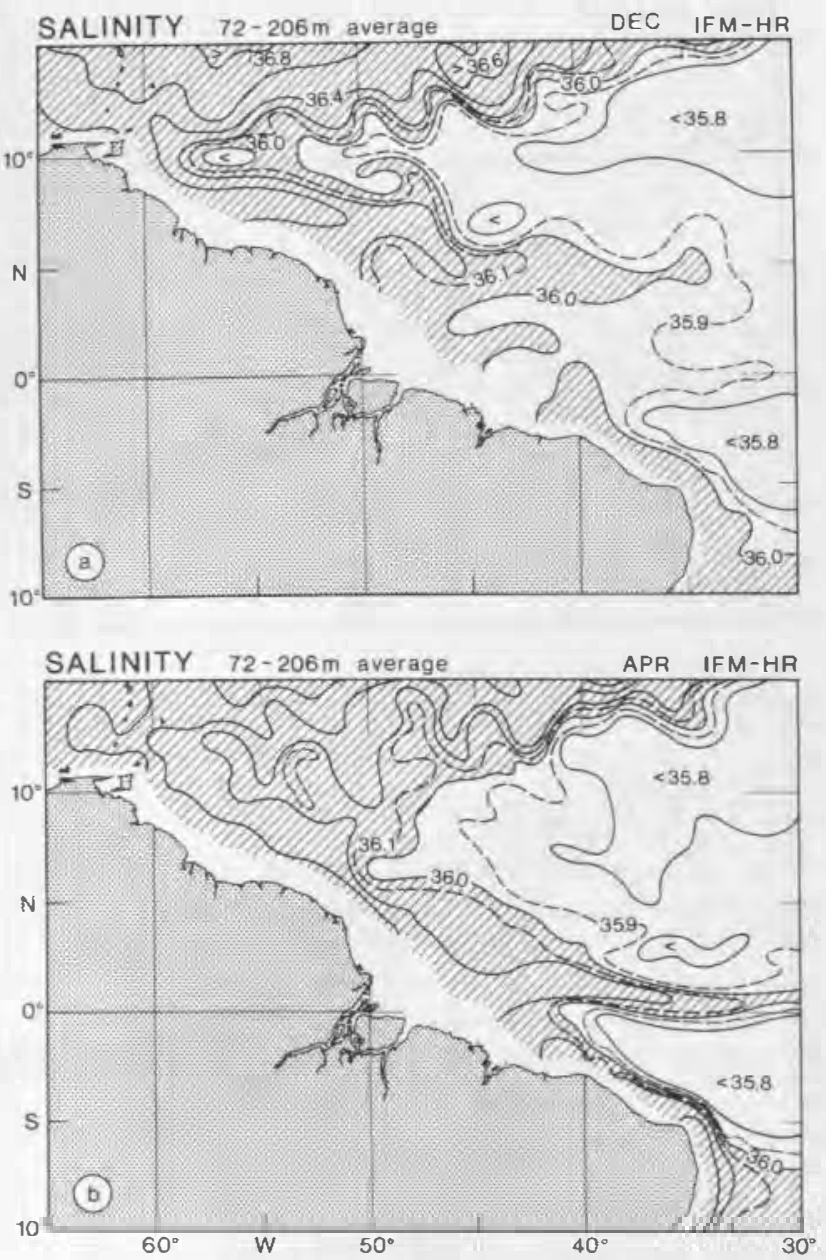

Fig. 4. Salinity, a veraged for layer $72-206 \mathrm{~m}$, in IFM-HR model. (a) December and (b) April.

equator and merges with the high-salinity tongue stemming from the NBC south of the equator (Figure $4 b$ ).

An interesting feature is also the strong northward boundary current at $10^{\circ} \mathrm{S}$ at the $133-\mathrm{m}$ level that exists in both seasons and is a prominent feature of the mean current at that level (Figure 1). It is stronger than the surface current in both seasons. It is also expressed by high salinities at this level (Figure 4).

\section{Zønal Current Systems}

\section{Surface Currents}

Figure 5 shows a comparison of zonal currents at $30^{\circ} \mathrm{W}$, $5^{\circ} \mathrm{S}-15^{\circ} \mathrm{N}$ derived from two versions of the high-resolution model and of PP. During summer, all model solutions show an eastward flow between $3^{\circ}$ and $10^{\circ} \mathrm{N}$ : the NECC (Figure $5 a)$. There are substantial differences, however, with respect to the meridional structure of the NECC: both PP-HR and NCAR give a rather broad, single maximum, in agreement with drifter velocities and historical ship drifts (Figure $5 c$ ), whereas IFM-HR, and similarly IFM-IH, show bands of eastward flow with a narrow core at the equatorward flank of the NECC. The narrow core at $3^{\circ} \mathrm{N}$ is the meandering jet seen in Figure $2 a$, and the wider current at about $6^{\circ} \mathrm{N}$, a band that parallels the meandering jet. Due to the standing nature
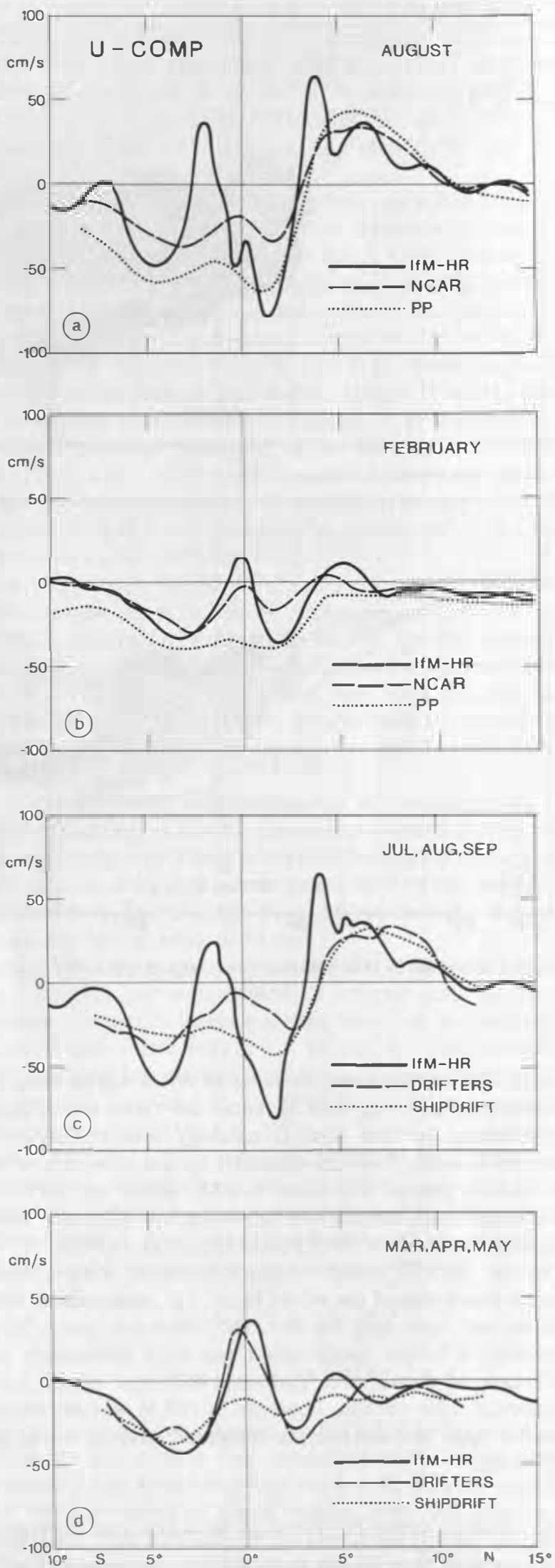

Fig. 5. Zonal surface currents at $30^{\circ} \mathrm{W}, 5^{\circ} \mathrm{S}-15^{\circ} \mathrm{N}$ from ship drifts and three models, IFM-HR, NCAR, and PP-HR (taken from Richardson and Philander [1986, Fig. 9]) in August and (b) Febru. ary. (c) Surface drifter velocities, ship drifts between $23^{\circ}$ and $35^{\circ} \mathrm{W}$ [from Richardson and Reverdin, 1987], and IFM-HR model currents at $30^{\circ} \mathrm{W}$ for July-September and (d) March-May. 
TABLE 1. Eddy Kinetic Energy (in $\mathrm{cm}^{2} \mathrm{~s}^{-2}$ ) of Surface Currents for Points A-D in Figure 1

\begin{tabular}{|c|c|c|c|c|c|c|c|}
\hline \multirow[b]{2}{*}{ Point } & \multirow[b]{2}{*}{ Location } & \multicolumn{3}{|c|}{ Total EKE } & \multicolumn{3}{|c|}{ Residual EKE of IFM-HR } \\
\hline & & IFM-HR & Ship Drifts* & $\mathrm{PP}^{*}$ & Total & July-Dec. & Jan.-June \\
\hline A & $5^{\circ} \mathrm{N}, 40^{\circ} \mathrm{W}$ & 1000 & 1400 & 700 & 25 & 35 & 15 \\
\hline B & $3^{\circ} \mathrm{N}, 40^{\circ} \mathrm{W}$ & 200 & 1200 & 500 & 28 & 48 & 8 \\
\hline C & $5^{\circ} \mathrm{S}, 40^{\circ} \mathrm{W}$ & 1050 & 1200 & 500 & 58 & 110 & 6 \\
\hline D & $10^{\circ} \mathrm{N}, 58^{\circ} \mathrm{W}$ & 170 & 1000 & 100 & 42 & 15 & 70 \\
\hline
\end{tabular}

Shown is total EKE of deviations from the annual mean, for IFM-HR, ship drifts, and PP model; and residual EKE of fluctuations about the 5-year mean annual cycle of IFM-HR, for two seasons, and averaged over the year.

*From Richardson and Philander [1987, Figure 4].

of the meanders, the averaging over 3 months (Figure $5 c$ ) does not significantly reduce the sharp peaks in the profiles. The low-friction cases show another eastward core just south of the equator, to be discussed below in conjunction with the EUC. During January to May, model currents in all versions are generally to the west in the western NECC regime (Figure $5 b$ ), in agreement with the observations (Figure $5 d$ ).

On the equator, both IFM model versions show eastward current in winter (Figure 5b), while PP shows westward currents there of about $50 \mathrm{~cm} \mathrm{~s}^{-1}$. These were in approximate agreement with the ship drifts (Figure $5 d$ ), but there is a suggestion in the surface velocities derived from drifters (Figure 5d) [Richardson and Reverdin, 1987] and from moored near-surface current measurements of Weisberg et al. [1987] that this eastward current might be real. The difference to the ship drifts may partly have to do with "windage," the set of ships through the water by the prevailing easterly winds, and partly with the fact that ship drifts are typically determined over 12 hours, i.e., more than $200 \mathrm{~km}$ for ship speeds of the past decades, where headings typically are close to normal to the current in that regions, thus averaging a small eastward core together with the westward flow to the north and south.

In comparing surface currents of the WOCE model versions and PP, one has to keep in mind that the latter is representative of a $10-\mathrm{m}$ surface layer, whereas the surface layer of the WOCE model is $35 \mathrm{~m}$ thick. For a better comparison, we determined the mean eastward component for the upper four layers, i.e., $40 \mathrm{~m}$, of PP-F. The result was reduced westward velocity due to the inclusion of the eastward shear layer below the surface, but eastward current on the equator was not obtained.

In comparison of the annual cycles of ship drift velocities in the western basin [Arnault, 1987] with the IFM-HR model for the NEC $\left(12-15^{\circ} \mathrm{N}\right)$, ship drifts only show a small seasonal variation west of $20^{\circ} \mathrm{W}$; near $30^{\circ} \mathrm{W}$, the maximum westward flow of about $15 \mathrm{~cm} \mathrm{~s}^{-1}$ occurs in April-June, in reasonable agreement with the model.

For the SEC branch north of the equator (NSEC; $1^{\circ}-3^{\circ} \mathrm{N}$ ), ship drifits near $30^{\circ} \mathrm{W}$ show a westward maximum of about 50 $\mathrm{cm} \mathrm{s}^{-1}$ in July/August (Figure $5 c$ ) and a minimum of about 20 $\mathrm{cm} \mathrm{s}^{-1}$ in April/May. Although the phase agrees again with the model, the seasonal amplitude of the model currents is larger with an eastward maximum of $80 \mathrm{~cm} \mathrm{~s}^{-1}$ in summer. For the SSEC $\left(1^{\circ}-5^{\circ} \mathrm{S}\right)$, ship drifts are $20-30 \mathrm{~cm} \mathrm{~s}^{-1}$ westward with no apparent annual cycle near $30^{\circ} \mathrm{W}$. The eastward surface jet of $40 \mathrm{~cm} \mathrm{~s}^{-1}$ near $2^{\circ} \mathrm{S}$ (Figure $5 a$ ) in summer appears totally unrealistic in comparison with measurements
(Figure $5 c$ ), while in winter, better agreement is obtained (Figure $5 d$ ).

In summary, the high-resolution model surface currents of the equatorial current system, while comparing reasonably well with surface current observations in winter, have a banded structure in summer. Velocities in these bands are significantly larger than those observed. Phases of the annual variations are generally in reasonable correspondence with ship drift observations. Averaging these currents for the summer period over the meander scale smooths the bands and brings maximum speeds down. Even for repetitive seasonal climatological wind forcing, the meanders will not be in the same place year after year. Hence, averaging individual meridional profiles like Figure $5 a$ for the model currents over consecutive years reduced the peaks of the current bands. Further, in reality, interannual variations of wind stress could also position the meanders differently in different years and thus result in smoother "model climatology" currents. The instantaneous meridional profiles are smoother in the high-friction (NCAR) model, which resembles the PP model the most of the three versions at the surface near $30^{\circ} \mathrm{W}$ (Figures $5 a, b$ ).

To distinguish seasonal and residual variations, we analyzed the variance for a 5 -year time series at a number of points in the western tropical region (Table 1). Generally it is found that most of the variance is due to the seasonal cycle. Point A, located in the center of the NECC (Figures 1, 2a), yields a total eddy kinetic energy (EKE) of $1000 \mathrm{~cm}^{2} \mathrm{~s}^{-2}$ but only $25 \mathrm{~cm}^{2} \mathrm{~s}^{-2}$ for the residual variations after the mean annual cycle is subtracted. Of this variance, $70 \%$ occurs during the meander season, July-December (Table 1). This EKE high continues as a narrow band along the meanders far eastward into the basin. Point B, located in the NSEC regime just $2^{\circ}$ south of point $A$ and typical for the model region away from the focused jets, has a total EKE of only $200 \mathrm{~cm}^{2} \mathrm{~s}^{-2}$. South of the equator there is another narrow, high-EKE belt, associated with the surface expression of the undercurrent.

In contrast, the PP model shows a broad EKE maximum in the retroflection zone and no penetration of the EKE high eastward along the NECC or of the second EKE high south of the equator. The residual EKE is typically an order of magnitude lower than that due to the annual cycle and concentrated in the meander season east of the retroflection area. Point $D$, near the entrance to the Caribbean, shows higher residual EKE during January-June, when the western NECC regime shows maximum mesoscale motions (Figure 3). Overall, compared to EKE from ship drift the EKEs of the IFM-HR model do not appear unrealistically high (Table 

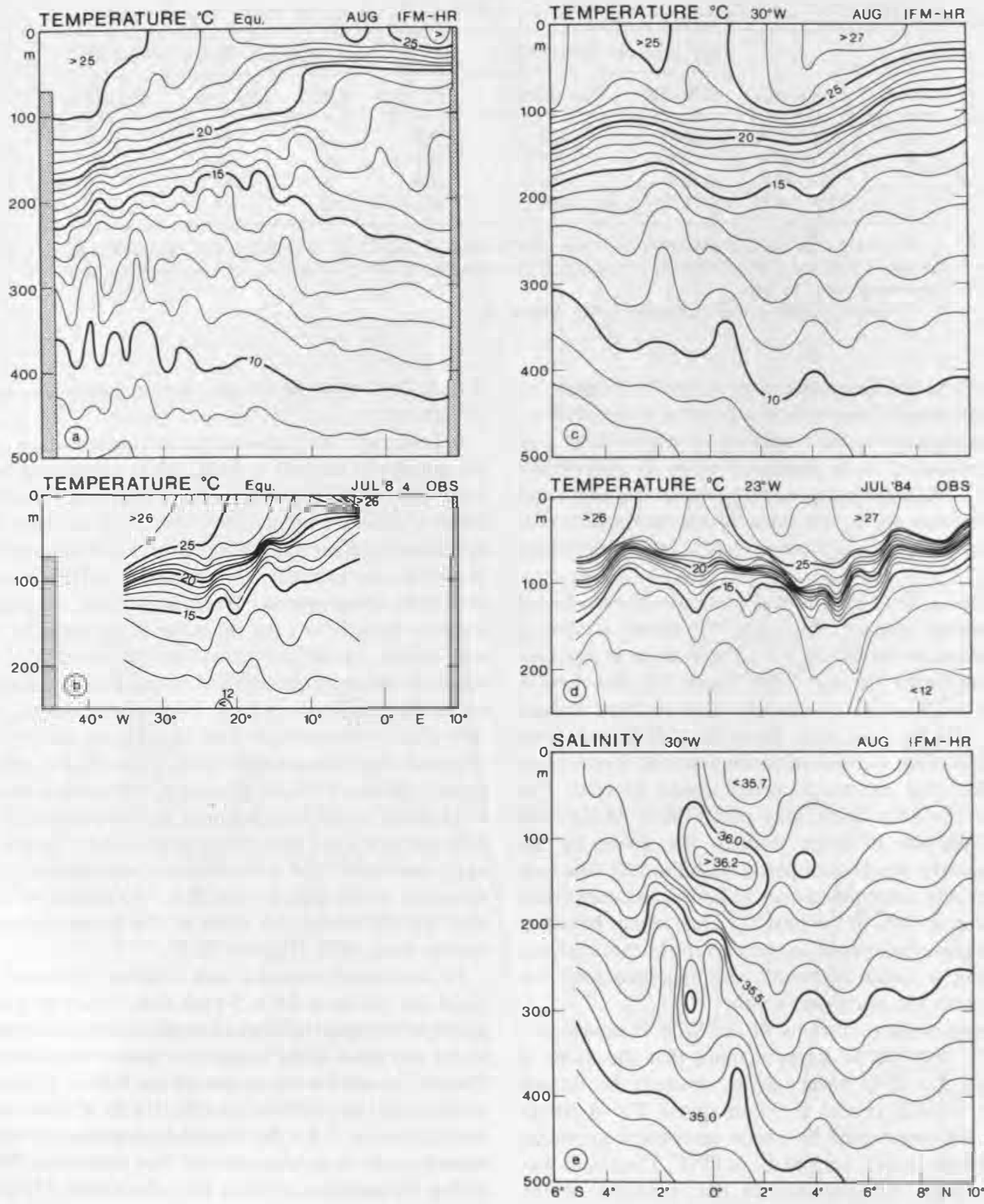

Fig. 6. (a) Temperature section along the equator from IFM-HR, August. (b) Observed temperature along equator, July-August 1984 [Hénin et al., 1986]. (c) Temperature section along $30^{\circ} \mathrm{W}, 6^{\circ} \mathrm{S}$ to $10^{\circ} \mathrm{N}$ from IFM-HR, August. (d) Same as Figure $6 c$, but along $23^{\circ} \mathrm{W}, 5^{\circ} \mathrm{S}$ to $10^{\circ} \mathrm{N}$. (e) Same as Figure $6 c$ but for salinity.

1). IFM-HR shares with PP the low EKE northwest of the retroflection, where ship drift EKEs show an elongated maximum until well into the Caribbean [Richardson and Philander, 1987]. The small residual EKE in IFM-HR implies that much of the mesoscale motion apparent in the current maps (Figure 2 ) is actually deterministic and part of the annual cycle.

\section{Equatorial Thermocline and Undercurrents}

The temperature section of IFM-HR for August, along the equator (Figure $6 a$ ), shows the upward and eastward slanting thermocline, but the thermocline is too diffuse by compari- son with observed temperatures (Figure $6 b$ ). It differs from PP (their Figure 7) in particular in the east, where in PP the temperature jump from $25^{\circ}$ to $16^{\circ} \mathrm{C}$ in July occurs between 30 - and $50-\mathrm{m}$ depth east of $10^{\circ} \mathrm{W}$. Similarly, the IFM-HR temperature section for August along $30^{\circ} \mathrm{W}$ (Figure $6 \mathrm{c}$ ) shows a too-diffuse thermocline compared to observations, in particular at the northern flank of the NECC (Figure $6 d$ ). The addition of a mixed layer model on top of IFM-HR has reduced this deficiency: it produces a more homogeneous surface layer and sharpens the thermocline where it is shallow.

The larger vertical mixing of NCAR compared to the IFM 
runs results in drastic differences in EUC penetration eastward. Meridional sections of NCAR and IFM-HR for February are shown in Figures $7 a$ and $7 b$. While in the west, both models do not differ all that much in currents and transports, the EUC decays eastward much faster in the NCAR case (Figure $7 a$ ); at $30^{\circ} \mathrm{W}$ the core speed is only 30 $\mathrm{cm} / \mathrm{s}$ compared to $90 \mathrm{~cm} / \mathrm{s}$ for IFM-HR (Figure $7 \mathrm{~b}$ ). In summer, there are two departures from present understanding of the zonal circulation. First, the high-speed current band near $4^{\circ} \mathrm{N}$ in the NECC on which we already commented is actually an identifiable current core (Figure $7 c$ ), separated from the weaker core near $6^{\circ} \mathrm{N}$ by near zero or even (below $200 \mathrm{~m}$ ) westward currents. Second is the existence of an eastward near-surface flow at $1^{\circ}-2^{\circ} \mathrm{S}$ (Figure $7 c$ ) with its isotachs connected to the EUC. The section in Figure $7 c$ bears some similarity to EUC sections in the western Indian Ocean [Leetmaa and Stommel, 1980] where eastward surface flow south of the equator was found near $55^{\circ} \mathrm{E}$ in the final phase of the seasonal existence of the EUC. The salinity maximum of the EUC also extends into the near-surface flow to its south (Figure 6e). Yet, in comparison with earlier sections in the western tropical Atlantic [e.g., Hisard and Hénin, 1987], this current pattern has to be considered unrealistic.

As already described, the EUC surfaces in the west in the low-friction version during late winter pushing the westward surface flow of the SEC apart with a band of eastward surface currents (Figures 3, 5, 7). This does not occur in PP (Figure $5 b$ ) even when averaged down to $40 \mathrm{~m}$ to correspond to the top layer of the WOCE model. Current profiling sections of Katz et al. [1981, Figure 3] show a surfacing of the undercurrent in three of four sections (for October, February, March); only in July the surface flow was westward, in agreement with IFM-HR. Near-surface eastward flow in spring was also observed by Weisberg et al. [1987] with moored current measurements at 10-m depth.

The annual cycle of the EUC transports at $30^{\circ} \mathrm{W}$ in IFM-HR has its maximum in September/October (Figure 8) with transports within the $20 \mathrm{~cm} \mathrm{~s}^{-1}$ isotach of $35.9 \mathrm{~Sv}$ (31.6 $\mathrm{S} v$ in the top $200 \mathrm{~m}$ ); minima occur in January/February with 19.5 Sv, and in June with 20.3 Sv (all in the top $200 \mathrm{~m}$ ). Katz et al. [1981] determined an annual mean EUC transport of 21 $S v$ within the $20 \mathrm{~cm} \mathrm{~s}^{-1}$ isotach and above $200 \mathrm{~m}$, for the 22 sections taken in the longitude range $25^{\circ}-33^{\circ} \mathrm{W}$ (Figure 8). The maximum of $44 \mathrm{~Sv}$ (based on a single section) was in early March with anomalously high surface currents (and reduces to about half when the near-surface layer is excluded), and the minimum in June/July. But in August, transports were back up to about $20 \mathrm{~Sv}$. Later data of Hisard and Hénin [1987] from the FOCAL cruises at $23^{\circ} \mathrm{W}$ had their maximum in fall: in both 1982 and 1983 the October values of 26 and 25 Sv, respectively, were the largest observed at that longitude in those 2 years. G. Reverdin (personal communication, 1990), in a reevaluation of all the earlier sections, obtained only a mean transport of $16.3 \mathrm{~Sv}$ across $35^{\circ} \mathrm{W}$, which would make the IFM-HR model mean of $24 \mathrm{~Sv}$ much too high.

Time series of moored currents over the upper $200 \mathrm{~m}$ on the equator at $28^{\circ} \mathrm{W}$ by Weisberg et al. [1987] during 19831985 do not show a detectable annual cycle of integrated transport per unit width. However, a conspicuous feature in the current profiles of Weisberg et al. [1987] is the seasonal depth variation of the EUC core, with a minimum in April/ May at about $70 \mathrm{~m}$, and maximum in late summer at about
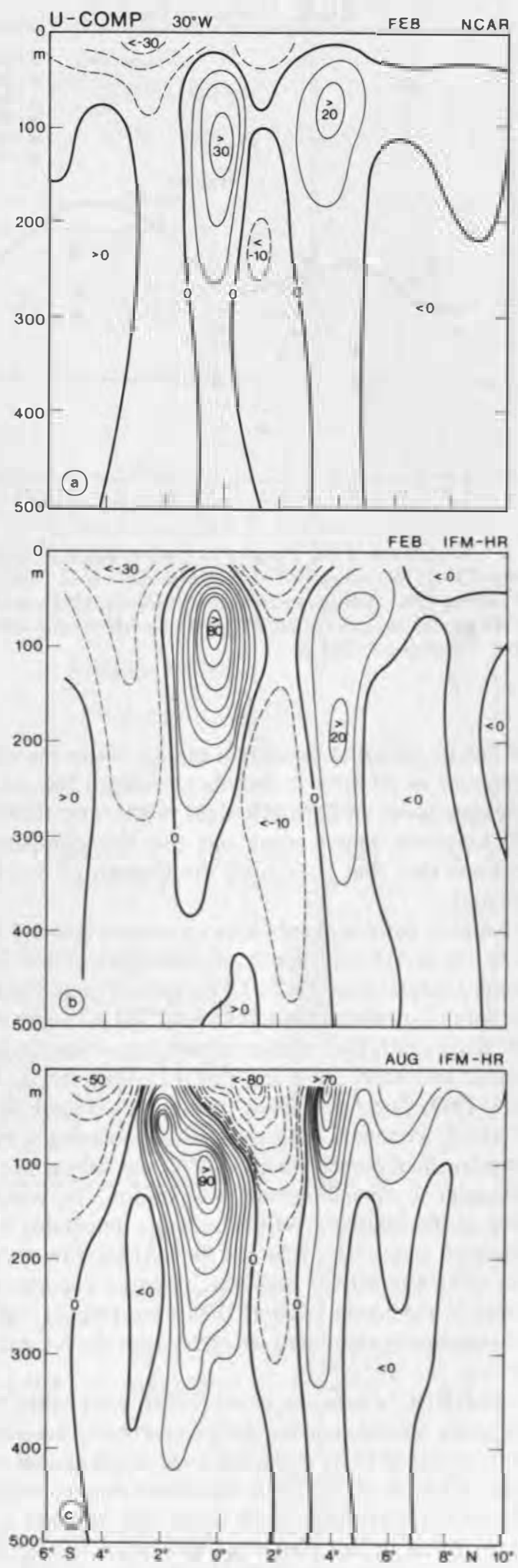

Fig. 7. Meridional section of zonal currents at $30^{\circ} \mathrm{W}$, upper $500 \mathrm{~m}$. (a) February NCAR, (b) February IFM-HR, (c) August IFM-HR.

$100 \mathrm{~m}$ that follows the displacements of the thermocline. This seasonal variation can be detected also in the model for the EUC core on the equator (Figures $7 b$ and $7 c$ ).

By comparison, the annual mean transport of PP-F at $30^{\circ} \mathrm{W}$, within the $20 \mathrm{~cm} \mathrm{~s}^{-1}$ contour and above $200 \mathrm{~m}$, is 12.4 


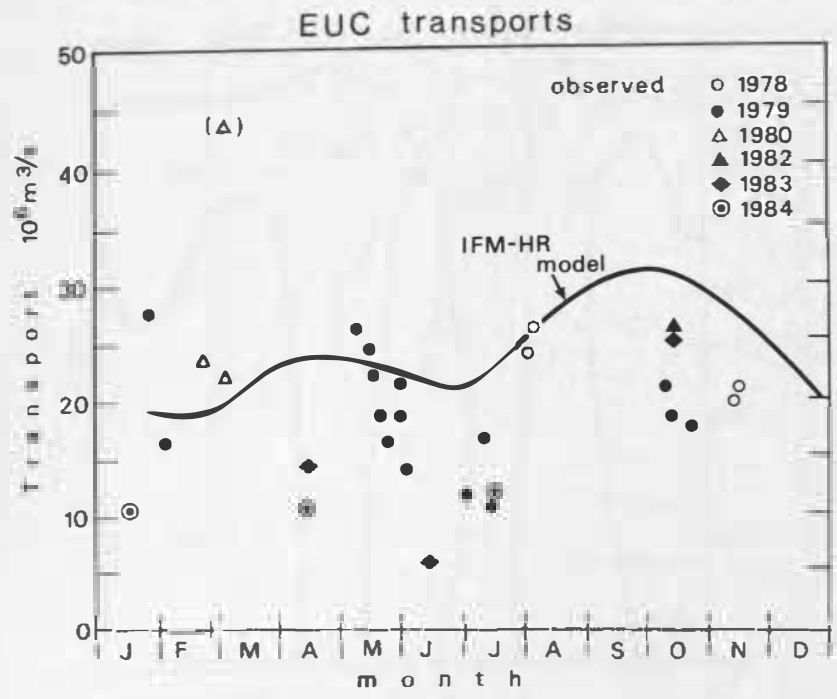

Fig. 8. Transports of the Equatorial Undercurrent in the longitude range $25^{\circ}-33^{\circ} \mathrm{W}$ during $1978-1980$ [from Katz et al., 1981], and at $23^{\circ} \mathrm{W}$ during 1982-1984 [from Hisard and Hénin, 1987]. Solid line is IFM-HR model transport at $30^{\circ} \mathrm{W}$. All transports are for velocities $>20 \mathrm{~cm} \mathrm{~s}^{-1}$ and above $200 \mathrm{~m}$.

Sv and has its seasonal maximum of $14.1 \mathrm{~Sv}$ in March and the minimum of $10.5 \mathrm{~Sv}$ in October. Toward the east the EUC decays faster in IFM-HR than in PP, and transports near $0^{\circ}$ longitude might come out too low compared to observations (but that is beyond the domain of this intercomparison).

A symmetric pattern of subsurface currents is found in the model to the north and south of the equator: the North Equatorial Undercurrent (NEUC) between $3^{\circ}$ and $5^{\circ} \mathrm{N}$ and a weaker South Equatorial Undercurrent (SEUC) south of $3^{\circ} \mathrm{S}$ (Figures $6 a$ and $6 b$ ). Both undercurrents have been found by geostrophic and water mass analysis [Cochrane et al., 1979; Molinari, 1982; Tsuchiya, 1986]. In summer (Figure 7c) the model NEUC connects with the NECC, forming a single, surface-intensified current band at $4^{\circ} \mathrm{N}$; the subsurface $(200$ $\mathrm{m})$ maximum is erased during this season. In winter, a signature of the eastward NECC remains detectable below the surface at about $5^{\circ} \mathrm{N}$, whereas the surface flow reverses north of $6^{\circ} \mathrm{N}$. The NECC and NEUC cores become separated only in the lower friction IFM case (Figure $7 b$ ); the vertical structure is smoothed out strongly in the NCAR case (Figure 7a).

For the NEUC, Cochrane et al. [1979], who called these undercurrents subthermocline countercurrents, determined a mean transport of $19 \mathrm{~Sv}$ and a decrease of the annual signal eastward. While at $40^{\circ}-50^{\circ} \mathrm{W}$ a significant annual variation existed, with a maximum of $26 \mathrm{~Sv}$ in late summer and a minimum of $9 \mathrm{~Sv}$ in late winter, no significant variation was found between $40^{\circ} \mathrm{W}$ and $28^{\circ} \mathrm{W}$. In the model a clearcut evaluation is only possible for the winter situation; then the undercurrent exists as an identifiable core (Figure $7 b$ ) with a transport of about $7 \mathrm{~Sv}$ across $44^{\circ} \mathrm{W}$, decreasing to $4 \mathrm{~Sv}$ at $30^{\circ} \mathrm{W}$. In summer, as mentioned above, the model does not show a subsurface current core in the NEUC latitude belt: transport in the $72-500 \mathrm{~m}$ range in August is $21 \mathrm{~Sv}$ at $44^{\circ} \mathrm{W}$, decreasing to $9 \mathrm{~Sv}$ at $30^{\circ} \mathrm{W}$. The southern hemisphere undercurrent transports about $15 \mathrm{~Sv}$ eastward across 30 $35^{\circ} \mathrm{W}$ and the observed core depth lies between 150 and 200 m [Cochrane et al., 1979; Molinari, 1982]. Data coverage is not good enough to delineate a seasonal cycle.

In IFM-HR the SEUC is weak and located south of $4.5^{\circ} \mathrm{S}$ (Figure 7c). In the latitude range of the observed SEUC the net flow in the 72- to 519-m depth range is actually westward. (In the NCAR case it has its core depth farther north, at $4^{\circ} \mathrm{S}$; Figure 7a). The existence of these off-equatorial undercurrents is an interesting result, and the PP model does apparently not reproduce them. Their physics and supply routes deserve further study.

\section{Seasonal Transports and Upwelling}

\section{Transport Budgets for Summer and Winter}

The relation between section horizontal transports and upwelling becomes apparent from the transport budgets in Figure 9, which are composed similar to those of Philander and Pacanowski [1986b], though for smaller boxes. Transports are shown for the near-surface layer 0-72 $\mathrm{m}$, the undercurrent level $72-206 \mathrm{~m}$, and the layer $206-519 \mathrm{~m}$. Upwelling at 72,206 , and $519 \mathrm{~m}$ is shown in box centers. The equatorial belt is $2.5^{\circ} \mathrm{S}-2.5^{\circ} \mathrm{N}$, the NECC belt is $2.5^{\circ}-10^{\circ} \mathrm{N}$, and there is a southern SEC belt from $2.5^{\circ}-5^{\circ} \mathrm{S}$.

In August (Figure $9 a$ ), upwelling along the equator contributes from even below $500 \mathrm{~m}$. Between $30^{\circ}$ and $44^{\circ} \mathrm{W}$, the undercurrent is supplied by $22.3 \mathrm{~Sv}$ from the north (SEC and NECC meander recirculation, Figure $7 c$ ) and by $13.7 \mathrm{~Sv}$ via the SEC/NBC from the south. It loses $2.3 \mathrm{~Sv}$ to the west at $44^{\circ} \mathrm{W}$, and loses $11.8 \mathrm{~Sv}$ more to the top layer than it gains from the bottom layer through upwelling. The result is 21.9 Sv eastward across $30^{\circ} \mathrm{W}$

In the NECC belt in August, there is downwelling from the top layer and upwelling across $206 \mathrm{~m}$, causing a transport maximum of the NECC in the 72- to 206-m layer. There is 10.3 Sv feeding into the NECC from west of $53^{\circ} \mathrm{W}$, which is mostly recirculation of NEC water partially supplied via the undercurrent off Guyana. Double that amount comes from the NBC across $2.5^{\circ} \mathrm{N}$, resulting in a total eastward transport across $30^{\circ} \mathrm{W}$ of $37.6 \mathrm{~Sv}$ in the upper $500 \mathrm{~m}$. This transport value is lower than the $54 \mathrm{~Sv}$ estimated by Richardson and Reverdin [1987] from combined drifter and moored velocities (which the authors themselves considered to be on the high side), but close to the estimate of Cochrane et al. [1979], who gave $35 \mathrm{~Sv}$ for $33^{\circ} \mathrm{W}$ in August; it is about double the transport of the PP model. The SSEC supplies $36.9 \mathrm{~Sv}$ across $35^{\circ} \mathrm{W}$, of which $20.9 \mathrm{~Sv}$ are entering the region across $5^{\circ} \mathrm{S}$ as a southern hemisphere boundary current, which is an undercurrent with a transport maximum in the 72- to 206-m layer.

The Caribbean inflow box shows that the 7.4 Sv entering the Caribbean in the upper $500 \mathrm{~m}$ in August (Figure 9a) are mainly stemming from the $16.9 \mathrm{~Sv}$ westward transport of the NEC that, together with upwelling of $1.3 \mathrm{~Sv}$ from below 500 $\mathrm{m}$, feeds that inflow and supplies $11.3 \mathrm{~Sv}$ into the NECC.

In February the EUC carries $13.6 \mathrm{~Sv}$ across $30^{\circ} \mathrm{W}$, which is made up of $13.2 \mathrm{~Sv}$ from the SEC/NBC but in contrast to the summer situation by only $1.8 \mathrm{~Sv}$ from the north, by about $2 \mathrm{~Sv}$ across $44^{\circ} \mathrm{W}$ from the Guyana Undercurrent, and it loses 3.6 Sv more across the $72-\mathrm{m}$ level through upwelling than it gains from below. The NECC carries now $2.7 \mathrm{~Sv}$ westward across $44^{\circ} \mathrm{W}$, and the NEUC is detectable below, at $2.6 \mathrm{~Sv}$. The SEC now brings only $23.8 \mathrm{~Sv}$ across $35^{\circ} \mathrm{W}$ in the upper $550 \mathrm{~m}$, of which $14.3 \mathrm{~Sv}$ are coming from the east 

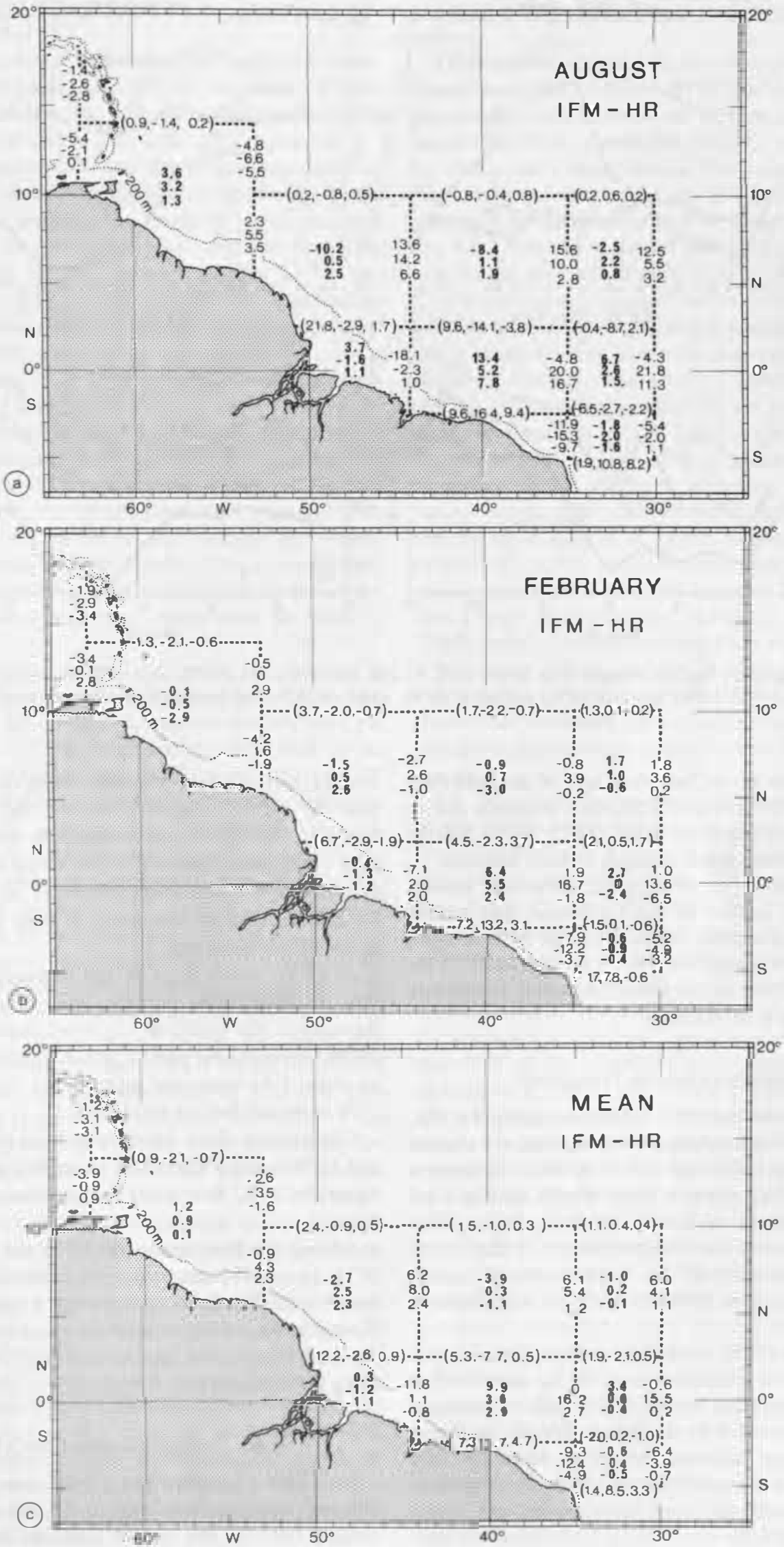

Fig. 9. Transports of IFM-HR model across box boundaries $(0-72 \mathrm{~m}, 72-206 \mathrm{~m}, 206-519 \mathrm{~m})$, marked at box boundaries, and upwelling across levels $(72,206,519 \mathrm{~m})$, marked heavy in box centers. (a) August, (b) February, (c) annual mean. Positive is eastward, northward, and upward. 

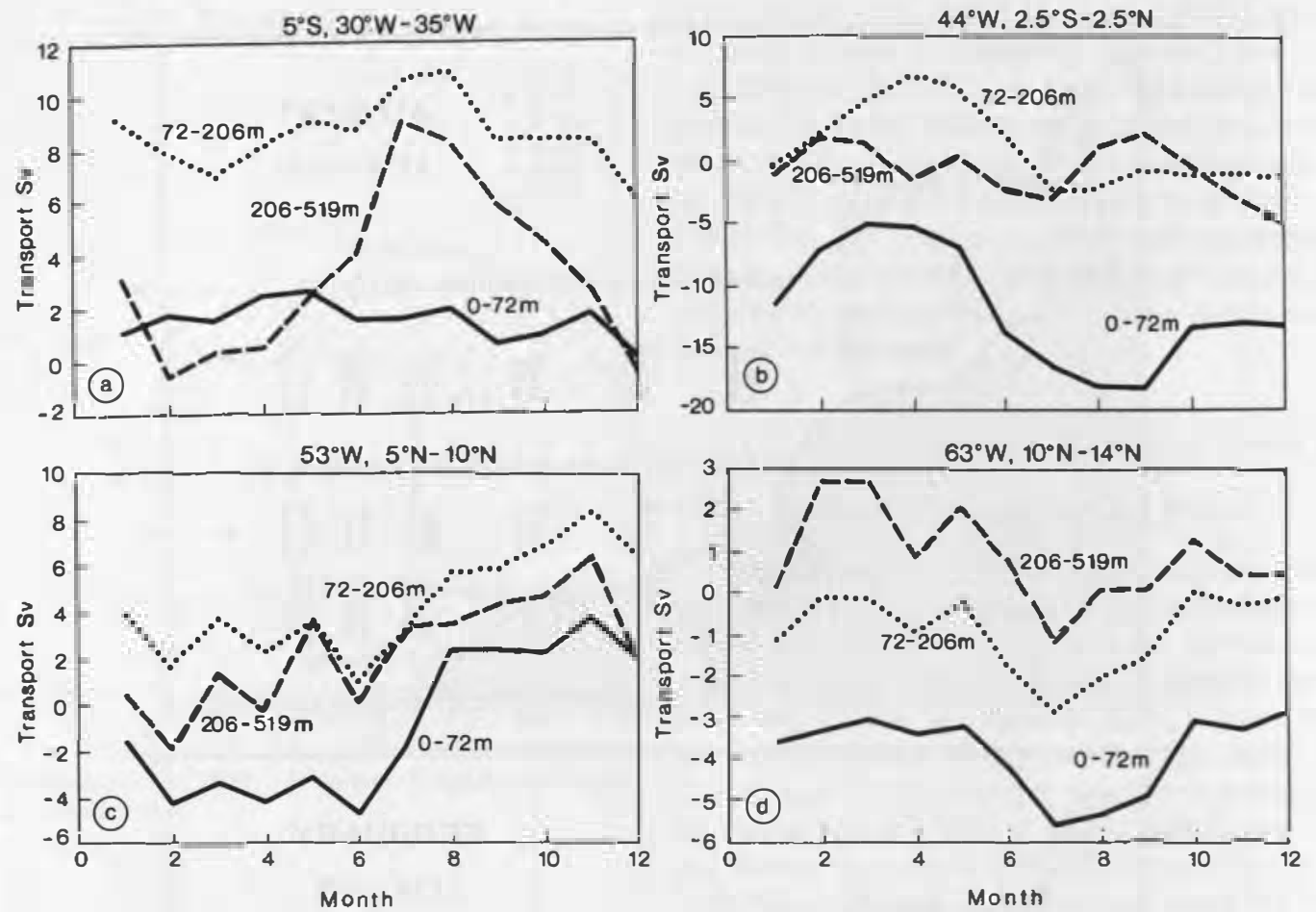

Fig. 10. Boundary current transports in layers 0-72, 72-206, 206-579 $\mathrm{m}($ a $)$ at $5^{\circ} \mathrm{S}$, west of $35^{\circ} \mathrm{W},(\mathrm{b})$ at $44^{\circ} \mathrm{W}$, south of $2.5^{\circ} \mathrm{N},(c)$ at $53^{\circ} \mathrm{W}$, south of $10^{\circ} \mathrm{N}$, and $(d)$ at $63^{\circ} \mathrm{W}$, south of $14^{\circ} \mathrm{N}$. For locations of sections, see Figure 1 .

and only 8.9 from the south, less than half of the boundary inflow in summer. This transport difference is mainly due to the 206- to 519-m level transport, while the 72- to 206-m level undercurrent is of about equal strength in both seasons.

The Caribbean inflow box (Figure $9 b$ ) shows the coastal undercurrent of $2.8 \mathrm{~Sv}$ out of the Caribbean that almost compensates the near-surface inflow south of $14^{\circ} \mathrm{N}$. Almost no upper layer flow is supplied by the NEC across $53^{\circ} \mathrm{W}$ (in summer it was $16.9 \mathrm{~Sv}$ ) and there is downwelling in that box compared to upwelling in summer.

\section{Annual Cycles of Boundary Current Transports}

Section transports in the three layers are given for $5^{\circ} \mathrm{S}$, $44^{\circ} \mathrm{W}$, and $53^{\circ} \mathrm{W}$ where measurement programs are carried out, and $63^{\circ} \mathrm{W}$ as the Caribbean inflow section. Transports across $5^{\circ} \mathrm{S}$ (Figure $10 a$ ) show a fairly steady equatorward undercurrent of 8-10 Sv in the 72- to 206-m layer. Flow above is nearly zero; and the transport below, in the 206- to 519-m layer, is characterized by a large annual signal, ranging from near zero in February to $9 \mathrm{~Sv}$ northward in July.

At $44^{\circ} \mathrm{W}$, south of $2.5^{\circ} \mathrm{N}$, the largest transport variation is in the top layer, with a maximum of $18 \mathrm{~Sv}$ westward in August/September supplied by the SSEC inflow maximum then, and a minimum of $5 \mathrm{~Sv}$ in spring. The 72- to 206-m layer shows maximum eastward transports during the first half of the year, when the undercurrent off Guyana feeds into the EUC, and transports are small in the second half, when it merges into the NECC.

At $53^{\circ} \mathrm{W}$, south of $10^{\circ} \mathrm{N}$, the westward surface transport has a maximum of $4 \mathrm{~Sv}$ in late winter to spring and changes to about 2 Sv eastward in late summer to fall, consistent with the assumption that there should be enhanced throughflow toward the Caribbean in winter when the NBC does not feed into the NECC (Figure 10c). At the two deeper levels, however, transports are dominantly eastward with the annual cycles about parallel to the surface transport, resulting in a combined maximum transport of $15 \mathrm{~Sv}$ eastward in October/November compared to near zero net flow of the upper $500 \mathrm{~m}$ in spring.

At $63^{\circ} \mathrm{W}$, south of $14^{\circ} \mathrm{N}$, the transport cycle differs from that at $53^{\circ} \mathrm{W}$. The surface layer transport is westward throughout the year with a brief maximum in July. The deeper levels show similar annual cycles superimposed on an about $1 \mathrm{~Sv}$ westward mean in the $72-$ to 206-m layer and I Sv eastward for the third layer.

Comparison of the seasonal section transports at $44^{\circ}, 53^{\circ}$, and $63^{\circ} \mathrm{W}$ suggest that there is no free connection of crossequatorial NBC flow along the Guyana coast into the Caribbean.

Adding the flow across $63^{\circ} \mathrm{W}$ in the latitude range $14^{\circ}$ $18^{\circ} \mathrm{N}$, i.e., to the northern limit of the Caribbean (Figure 9) would add 7.3 Sv westward in August, and 8.9 Sv in February. Hence the bulk of the eastern Caribbean inflow in the model enters as part of the NEC, not as throughflow along the boundary.

\section{Summary and Conclusions}

The WOCE community model was evaluated in two different versions (one run at NCAR and one, of lower vertical friction, run at IfM Kiel) for its seasonal cycle of upper layer currents and transports in the western tropical Atlantic, with special emphasis on a cross-equatorial section at $30^{\circ} \mathrm{W}$, and on sections along the boundary, from south of the equator to the Caribbean. Several results appear remark- 
able, and some notable differences occur in comparison with the equatorial model of PP.

1. The salient features of the equatorial current system, in particular, the retroflection of the NBC into the NECC are robust results of the model and reproduced independently of the vertical eddy momentum diffusion coefficient used.

2. The diffuse thermocline and lack of eastward penetration of the EUC are obvious deficiencies of the model. In the low-friction IFM-HR version, the transport, while too high at $30^{\circ} \mathrm{W}$, drops off too fast farther east, and for the higher friction NCAR case, the EUC barely reaches $30^{\circ} \mathrm{W}$. The maintenance of the EUC at the top of the thermocline requires vertical friction parameterization that is dependent on stability as in PP. Concerning the thermocline, some focusing was achieved in an IFM model expansion where a Kraus-Turner mixed layer was added.

3. The retroflection regime merges into meanders of about $700-\mathrm{km}$ wavelength which remain stable during August-December and then dissolve fairly suddenly. The fact that meanders east of the retroflection zone actually exist has been shown by drifter tracks [Richardson and Walsh, 1986] and satellite color imagery [Muller-Karger et al., 1988; Johns et al., 1990]. What appears unrealistic is the persistence of the meanders and their penetration far into the interior.

4. While for the December-June period the currents in the low-friction case compare well with observations, remarkable eastward jets appear during the retroflection period, July-December. Then, two separate cores exist in the NECC, of distinctly higher velocity than in either the PP model or the climatologically observed means; especially unrealistic appears an eastward jet embedded in the westward SEC just south of the equator. In the observations, separate eastward cores can occasionally occur in the NECC regime [Hénin and Hisard, 1987], and Geosat altimetry evaluation also showed two bands of eastward anomalies in the NECC. Their occurrence in the model is a sole consequence of the mixing parameterization used. They occur in IFM-HR but neither in the higher vertical-friction NCAR model $\left(30 \mathrm{~cm}^{2} \mathrm{~s}^{-2}\right)$ nor in the PP model that has higher horizontal friction. These banded jets are stable features of the low-friction model version which appear year after year in almost the same place. Even a further reduction of the horizontal mixing parameters in the IFM model only increased the strength of these jets but did not cause them to break down.

As shown by Cox [1980], wave radiation of energy away from the instability areas can provide an effective stabilization mechanism in near-equatorial regions. Because of the stability of the standing meanders, surface current variance is dominantly due to seasonal variation; deviations from the 5-year mean annual cycle are small. Most of the residual variance in the zonal current system occurs in the meander season, July-December, while northwest of the retroflection region the other part of the year shows higher residual variance. These model jets during the meander period deserve further study as to their kinematics and energy budget. To what degree they are realistic is difficult to tell from the present observational basis.

5. The model produces various off-equatorial undercurrents. It is interesting that it shows the northern and southern hemisphere subthermocline countercurrents described, e.g., by Cochrane et al. [1979], which apparently the PP model does not. This subject also deserves further investigation.

The model also produces two equatorward undercurrents along the coast. Intriguing in the model results is the equatorward undercurrent off Guyana, in the depth range of about $100-300 \mathrm{~m}$, that is fed partially out of the Caribbean, by high-salinity recirculation flow originating in the NEC. This undercurrent feeds into the NECC in summer and continues toward the equator in winter to merge there with the NBC into the eastward flowing EUC. This current has been found in recent observations by Johns et al. [1990] and C. Colin (personal communication, 1989). Indications of this undercurrent also exist in the PP model but are much weaker there. It can be seen also in the currents of the world ocean model of Semtner and Chervin [1988]. Less clear is the realism of a northward undercurrent in the model along the coast between $5^{\circ}$ and $10^{\circ} \mathrm{S}$. That current, in the model, is fed by zonal inflow in the latitude range $11^{\circ}-13^{\circ} \mathrm{S}$. With the closeness of the southern boundary where the model is forced to adapt the Levitus [1982] climatology, this could well be an artifact of this particular model. However, indications of such an undercurrent can be seen also in the coarse-resolution model of Sarmiento [1986, Figure 4a] that uses a larger model domain, and in the Semtner and Chervin [1988] model. This undercurrent has not been mentioned as a persistent feature in the literature, but inspection of individual ship sections from $35^{\circ} \mathrm{W}$ [Hénin et al., 1986] shows that westward subsurface geostrophic velocity maxima at the southern end of that section, north of Cape Rocas, can exist.

6. The issue of prominent importance to us in the context of this study is the pathway of upper layer flow from the southern hemisphere into the Caribbean in the western boundary regime. And there it is surprising how small the transport is that actually enters the Caribbean across $63^{\circ} \mathrm{W}$ along the southern boundary, south of $14^{\circ} \mathrm{N}$, corresponding to passage inflows south of Martinique: a mean of $4.8 \mathrm{~Sv}$ westward in the upper $206 \mathrm{~m}$ (Figure 9c), a counterflow of $0.9 \mathrm{~Sv}$ eastward from there down to $519 \mathrm{~m}$, and another 0.3 $\mathrm{Sv}$ westward in the deep layers, totaling only $4.2 \mathrm{~Sv}$, or less than $20 \%$ of the Florida Current transport of that model [Böning et al., 1991]. However, between $14^{\circ}$ and $18^{\circ} \mathrm{N}$, the mean Caribbean inflow is $7.4 \mathrm{~Sv}$ in the upper $500 \mathrm{~m}$ (Figure $9 c)$ plus $0.5 \mathrm{~Sv}$ below, suggesting the NEC as supply route.

Regarding the water mass transfer aspect, a special feature of the WOCE model is its low transport in the meridional cell: the deep western boundary current (DWBC) transports only about $6 \mathrm{~Sv}$ across $53^{\circ} \mathrm{W}$ toward the equator and onward along the boundary, across $5^{\circ} \mathrm{S}$. This value appears to be low by comparison with data inversions [e.g., Wunsch, 1984] and results in a heat flux across $25^{\circ} \mathrm{N}$ of only $0.7 \times 10^{15} \mathrm{~W}$; in contrast, the global model of Semtner and Chervin [1988] has a DWBC transport across $5^{\circ} \mathrm{S}$ of $14 \mathrm{~Sv}$ southward, which contributes the "conveyer belt" global circulation [Gordon, 1986]. It appears that the width of only $2^{\circ}$ of the southern buffer zone in the WOCE model, in contrast to the $10^{\circ}$ wide zone used by Sarmiento [1986], is not effective enough to close the thermohaline cell. This transport deficit may be part of the reason why the IFM-HR transport in the Florida Current is only $23 \mathrm{~Sv}$ [Böning et al., 1991].

Concerning the annual cycle along the boundary, the WOCE model section transports presented here do not confirm earlier postulations, namely, that the cross- 
equatorial NBC flow turns into the NECC in summer but continues along the North Brazil and Guyana coast toward the Caribbean in winter, when the NECC is weak or even reversing. To resolve the pathways of the water mass exchange across the equator and into the Caribbean, Langrangian particle methods in the model and more detailed water mass analysis need to be applied.

Acknowledgments. We thank F. Bryan (NCAR) for providing output fields of the NCAR Community Modeling Effort (CME), G. Philander (Princeton University) for letting us have output of his equatorial Atlantic model, B. Semtner (Naval Postgraduate School) for making available transport numbers of his most recent model runs, and G. Reverdin (LODYC/Lamont) for supplymg new undercurrent transport numbers. The help of R. Döscher and R. Budich in running the IFM model at the CRAY X-MP of Kiel University, and of M. Visbeck (IfM Kiel) in the model evaluation is greatly appreciated. We thank S. Wacongne (IfM Kiel), R. Molinari (NOAA/ AOML Miami), and G. Philander (NOAA/GFDL Princeton) for helpful comments. This study was supported by Deutsche Forschungsgemeinschaft, SFB 133.

\section{REFERENCES}

Arnault, S., Tropical Atlantic geostrophic currents and ship drifts, J. Geophys. Res., 92, 5076-5088, 1987.

Böning, C. W., R. Döscher, and H.-J. Isemer, Monthly mean wind stress and Sverdrup transport in the North Atlantic: A comparison of the Hellerman-Rosenstein and Isemer-Hasse climatologies, J. Phys. Oceanogr., 21, 221-129, 1991.

Bryan, F. O., and W. R. Holland, A high resolution simulation of the wind-and thermohaline-driven circulation in the North Atlan tic Ocean, Parameterization of small-scale processes, Spec. Publ. 99116, Hawaii Inst. of Geophys., 1989.

Bryan, K., A numerical method for the study of the circulation of the World Ocean, J. Comput. Phys., 4, 347-376, 1969.

Cochrane, J. D., F. J. Kelly, Jr., and C. R. Olling, Subthermocline countercurrents in the western equatorial Atlantic Ocean, $J$. Phys. Oceanogr., 9, 724-738, 1979.

Cox, M. D., Generation and propagation of 30-day waves in a numerical model of the Pacific, J. Phys. Oceanogr., 10, 11681186,1980

Cox, M. D., A primitive equation, 3-dimensional model of the ocean, Ocean Group Tech. Rep. 1, 143 pp., Geophys. Fluid Dyn. Lab., Princeton, N.J., 1984.

Gordon, A., Interocean exchange of thermocline water, J. Geophys. Res., 9I, 5037-5046, 1986.

Hall, M. M., and H. L. Bryden, Direct estimates and mechanisms of ocean heat transport, Deep Sea Res., 29, 339-359, 1982.

Han, Y., A numerical world ocean circulation model, 11, Dyn. Atmos. Oceans, 8, 141-172, 1984.

Hellerman, S., and M. Rosenstein, Normal monthly wind stress over the World Ocean with error estimates, J. Phys. Oceanogr. $13,1093-1105,1983$

Hénin, C., and P. Hisard, The North Equatorial Countercurrent observed during the Programme Franıçais Océan et Climate Dans l'Atlantique Equatorial Experiment in the Atlantic Ocean, July 1982 to August 1984, J. Geophys. Res., 92, 3751-3758, 1987.

Hénin, C., P. Hisard, and B. Piton, FOCAL, vol. 1, Observations hydrologiques dans l'Océan Atlantique Equatorial (juillet 1982 août 1984), Editons de l'ORSTOM Collect. Trav. et Doc., 196, 191 pp., ORSTOM, 1986.

Hisard, P., and C. Hénin, Response of the equatorial Atlantic Ocean to the 1983-1984 wind from the Programme Français Océan et Climate Dans l'Atlantique Equatorial Cruise data set, J. Geophys. Res., 92, 3759-3768, 1987.

Isemer, H.-J., und L. Hasse, The BUNKER Climate Atlas of the
North Atlantic Ocean, vol. 2, Air-Sea Interactions, 256 pp., Springer, New York, 1987.

Johns, W. E., T. N. Lee, F. A. Schott, R. J. Zantopp, and R. H. Evans, The North Brazil Current retroflection: Seasonal structure and eddy variability. J. Geophys. Res., 95, 22,103-22,120, 1990.

Katz, E. J., R. L. Molinari, D. E. Cartwright, P. Hisard, H. U. Lass, and A. deMesquita, The seasonal transport of the Equatorial Undercurrent in the western Atlantic (during the Global Weather Experiment), Oceanol. Acta, 4(4), 445-450, 1981.

Kraus, E. B., and J. S. Turner, A one-dimensional model of the seasonal thermocline, II, The general theory and its consequences, Tellus, 19, 98-106, 1967.

Leetmaa, A., und H. Stommel, Equatorial current observations in the western Indian Ocean during 1975 and 1976, J. Phys. Oceanogr., 10, 258-269, 1980.

Levitus, S., Climatological Atlas of the World Ocean, NOAA Prof. Pap. 13, 173 pp., 1982.

Metcalf, W. G., und M. C. Stalcup, Origin of the Atlantic Equatorial Undercurrent, J. Geophys. Res., 72, 4959-4974, 1967.

Molinari, R. L., Observations of eastward currents in the tropical South Atlantic Ocean: 1978-1980, J. Geophys. Res., 87, 97079714, 1982.

MullerKarger, F. E., C. R. McClain, and P. L. Richardson, The dispersal of the Amazon's water, Nature, 333, 57-59, 1988.

Olson, D., F. Schott, R. Zantopp, and K. Leaman, The mean circulation east of the Bahamas as determined from a recent measurement program and historical XBT data, J. Phys. Oceanogr., 14, 1470-1487, 1984.

Philander, G., and R. C. Pacanowski, A model of the seasonal cycle in the Tropical Atlantic Ocean, J. Geophys. Res., 91, 14,19214,206, 1986a.

Philander, G., and R. C. Pacanowski, The mass and heat budget in a model of the Tropical Atlantic Ocean, J. Geophys. Res., 91, $14,212-14,220,1986 b$.

Richardson, P. L., and S. G. H. Philander, The seasonal variations of surface currents in the tropical Atlantic Ocean: A comparison of ship drift data with results from a general circulation model, $J$. Geophys. Res., 92, 715-724, 1987.

Richardson, P. L., and G. Reverdin, Seasonal cycle of velocity in the Atlantic North Equatorial countercurrent measured by sur face drifters, current meters and ship drifts, J. Geophys. Res., 92, $3691-3708,1987$.

Richardson, P. L., and D. Walsh, Mapping climatological seasonal variations of surface currents in the tropical Atlantic using ship drift data, J. Geophys. Res., 9I, 10,537-10,550, 1986.

Sarmiento, J. L., On the North and Tropical Atlantic heat balance, J. Geophys. Res., 91, 11,677-11,689, 1986.

Schmitz, W. J., Jr., und L. Richardson, On the sources of the Florida Current, J. Phys. Oceanogr., in press, 1991.

Semtner, A. J., Jr., and R. M. Chervin, A simulation of the global ocean circulation with resolved eddies, J. Geophys. Res., 93, $15,502-15,522,1988$.

Tsuchiya, M., Thermostads and circulation in the upper layer of the Atlantic, Ocean. Progr. Oceanogr. 16, 235-267, 1986.

Weisberg, R. H., J. H. Hickman, T. Y. Tang, and T. J. Weingartner, Velocity and temperature observations during the seasonal response of the Equatorial Atlantic Experiment at $0^{\circ}, 28^{\circ} \mathrm{W}, J$. Geophys. Res., 92, 5061-5075, 1987.

Wunsch, C., An eclectic Atlantic Ocean ocean circulation model, 1, The meridional flux of heat, J. Phys. Oceanogr., 14, 1712-1733, 1984.

Wunsch, C., und D. Roemmich, Is the North Atlantic in Sverdrup balance?, J. Phys. Oceanogr., 15, 1876-1880, 1985

C. W. Böning and F. A. Schott, Institut für Meereskunde an der Universität Kiel, Duistembrooker Weg 20, D-2300 Kiel, Germany.

(Received July 25, 1990;

revised November 20, 1990;

accepted November 26, 1990.) 